
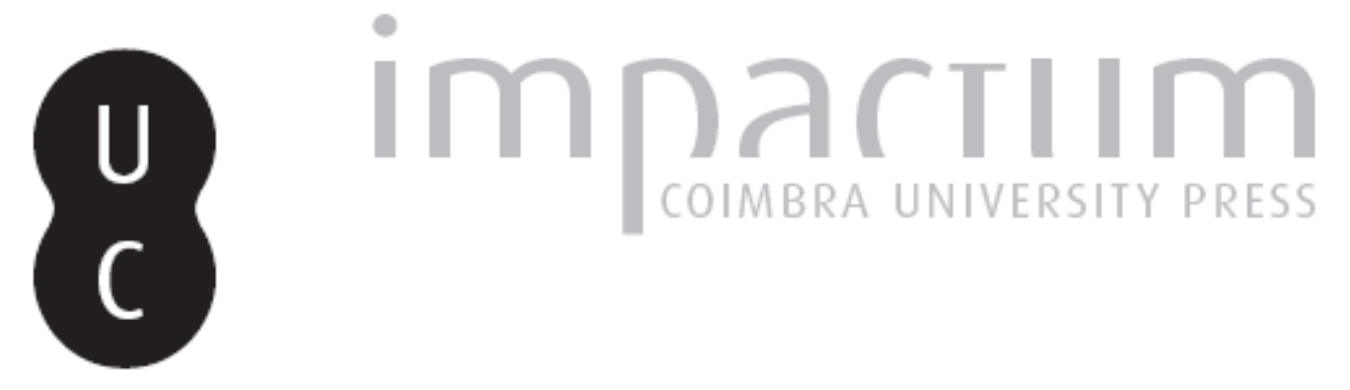

\title{
Alvalade neighbourhood: once modern never old (but age-friendly)
}

Autor(es): Carvalho, António

Publicado por: Editorial do Departamento de Arquitetura

URL persistente:

URI:http://hdl.handle.net/10316.2/45187

DOI:

DOI:https://doi.org/10.14195/1647-8681_9_9

Accessed : $\quad$ 26-Apr-2023 11:54:11

A navegação consulta e descarregamento dos títulos inseridos nas Bibliotecas Digitais UC Digitalis, UC Pombalina e UC Impactum, pressupõem a aceitação plena e sem reservas dos Termos e Condições de Uso destas Bibliotecas Digitais, disponíveis em https://digitalis.uc.pt/pt-pt/termos.

Conforme exposto nos referidos Termos e Condições de Uso, o descarregamento de títulos de acesso restrito requer uma licença válida de autorização devendo o utilizador aceder ao(s) documento(s) a partir de um endereço de IP da instituição detentora da supramencionada licença.

Ao utilizador é apenas permitido o descarregamento para uso pessoal, pelo que o emprego do(s) título(s) descarregado(s) para outro fim, designadamente comercial, carece de autorização do respetivo autor ou editor da obra.

Na medida em que todas as obras da UC Digitalis se encontram protegidas pelo Código do Direito de Autor e Direitos Conexos e demais legislação aplicável, toda a cópia, parcial ou total, deste documento, nos casos em que é legalmente admitida, deverá conter ou fazer-se acompanhar por este aviso.

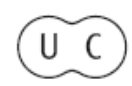



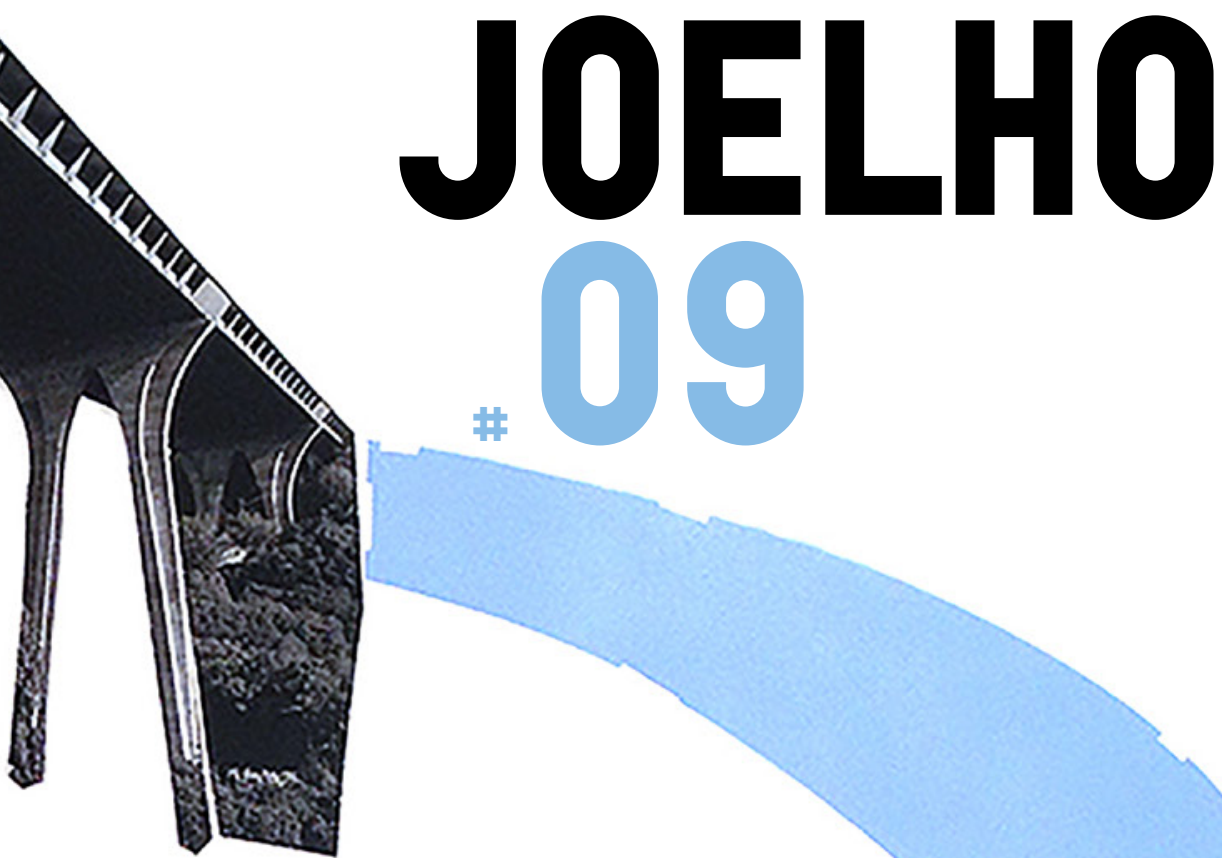

\section{REUSE OF MODERNIST BUILDINGS: PEDAGOGY AND PROFESSION}

Guest Editors:

Michel Melenhorst

Paulo Providência

Gonçalo Canto Moniz

ZUS: Elma van Boxel

and Kristian Koreman

Atelier do Corvo

Tilemachos Andrianopoulos

Albena Yaneva

Carlos Fortuna

Christian Gänshirt

Dieter Leyssen

Carolina Coelho

Anna Giovannelli

António Carvalho

Marta Peixoto

Els De Vos

and Eva Storgaard

Exhibition

$2^{\text {nd }}$ RMB Workshop, Coimbra

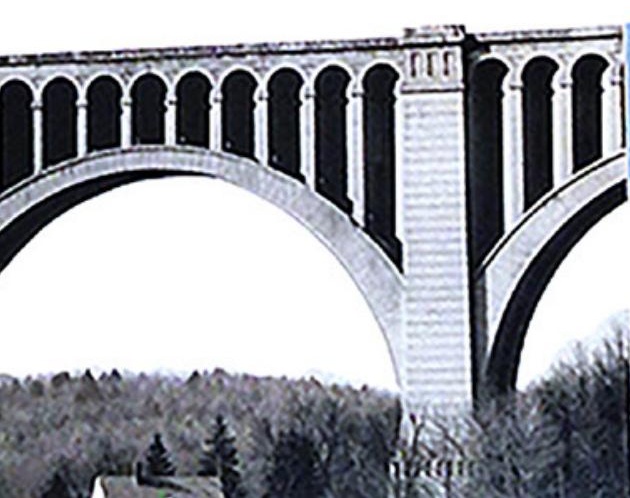




\section{António Carvalho \\ Âlvalade Neighhbourhood: once modern never old \\ (but age-íriend $\mathrm{I}_{\bar{y}} \mathbf{y}$ )}

Politecnico di Milano,

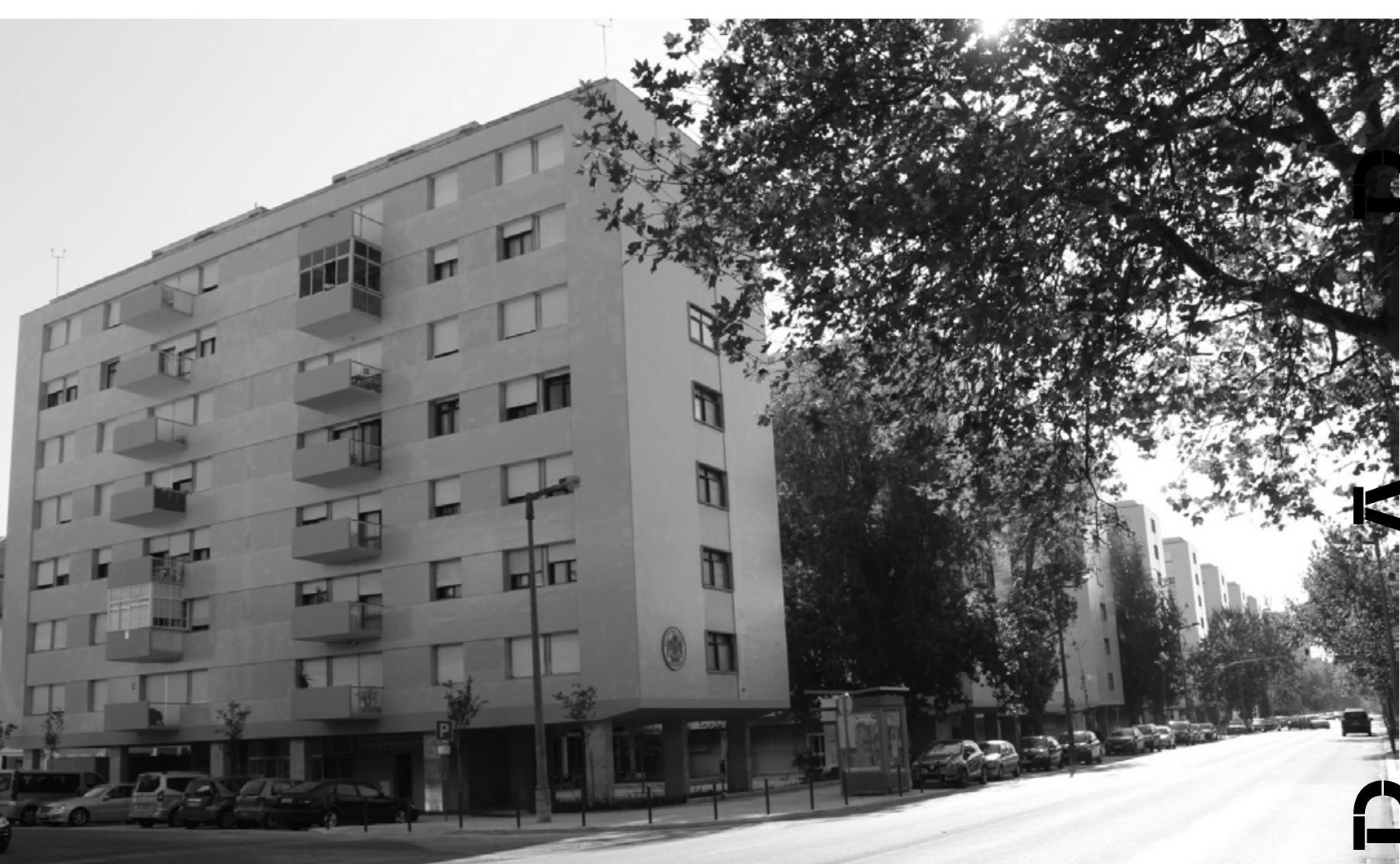




\section{Introduction}

The ageing of societies is a global concern, especially in Europe.

Portugal, the sixth most aged country in the world (UN, 2017), is already facing this new reality, namely, in its capital, Lisbon. The district of Alvalade, a modernist (MOD) neighbourhood built after 1945, is today a Naturally Occurring Retirement Community (NORC), therefore a good case study to analyse in which way modernist housing can cope with the ageing of its inhabitants. Besides, Alvalade was mostly built upon the strategic policy of repetition of architectural projects, to save money and build faster, resulting in dozens of similar buildings and hundreds of equal apartments. For us, this means ideal conditions to test ideas of reuse of modernist housing because of the many possibilities of location and replication throughout the neighbourhood.

This paper aims therefore at providing ideas and solutions for the transformation of existing apartment buildings into Assisted Living (AL) units for their older residents. These design proposals are the result of a previous research (Carvalho, 2010) in which a thorough literature review for concepts and survey of all existing AL facilities in the Greater Lisbon area was conducted, including interviews and site visits. This allowed us to conclude which spaces and services were present at all facilities, thereby classified as fundamental (restaurant, kitchen, lounge, nurse office), which ones were present in half of them, thereby classified as important (reception, administration office, laundry), and which ones were randomly present and thereby superfluous (central corridor, veranda corridor, storage room, medical office, physiotherapy, winter garden, library, porch). Following this field research, we selected repetitive projects of buildings in Alvalade whose characteristics would allow the introduction of fundamental spaces and provision of services to function as Assisted Living. The original projects were located at the municipal archives to confirm the initial characteristics (since many of them have undergone different changes through the past six decades), resulting in the selected case studies.

The three case studies we selected for this paper correspond to three levels or possibilities of intervention that we consider fundamental for an age-friendly city: public space (Bairro das Estacas), interiors (Av. Estados Unidos da América) and buildings (Av. do Brasil). Besides, they all share quite similar main modernist concepts in their spatial conception, thereby allowing the extrapolation and intertwining of conclusions. In that sense, the transparent ground floors of most modernist buildings offer shelter from sun and rain, while providing continuous public pedestrian paths away from traffic, while the rational and functional organization of interiors spaces provide clear and straight paths for better mobility for someone on a wheel-chair or using other walking aid devices. Sometimes, it also offers the possibility of co-housing or shared living arrangements between different generations while keeping autonomy and privacy inside the same apartment. Last but not least, modernist flat roofs can be used for leisure and social
Frontispiece Brasil Avenue, Alvalade, Lisbon, photo by the author 
interaction purposes, especially for the older age groups who feel too fragile to face the public space and yet need to do some soft exercise. The main issue we will therefore address in this article is how to reuse and adapt this modernist global environment (public spaces, buildings, and interiors), respecting its original design standards and yet turning it into an age-friendly community.

\section{Alvalade in the 1950's: young and MOD}

When the Alvalade neighbourhood was created, in the early 1950's, Portugal had quite a young population: the country had not been involved in the Second World War and the population pyramid was perfect, with a solid young base. Lisbon, as capital, attracted many people from smaller towns, especially from the countryside, and Alvalade represented the new expansion of the city northwards, where the city airport (a symbol of modernity) had been inaugurated in 1942. This new expansion (Fig. 1) was mainly intended to house the growing middle class, even though it also included the relocation of lower income families in "low rent" apartment buildings. Actually, for this emergency relocation reason, these were the first housing units to be built in compact corridor streets, in a clear hierarchy of main streets, secondary streets, cul-de-sac and pedestrian streets, following the neighbourhood unit concept (Perry, 1929), which the Alvalade Plan's author, Faria da Costa, named urban cells (CML, 1948). Among the eight urban cells into which the plan is organized, some parts would adopt a rather modernist layout, by influence of the architects who designed the buildings, with the urban designer's agreement- also as a lesson learned, since the common green spaces inside the urban blocks in the first built urban cells soon proved to be quite abandoned spaces (Costa, 2002), hidden from the street views. Three of these urban cells (Fig. 1) with modernist design will be our case studies in this paper: 1-Bairro das Estacas, 2Avenida dos Estados Unidos da America, 3-Avenida do Brasil.

\section{Bairro das Estacas, 1949}

This housing ensemble got instant fame in the city being nicknamed "Bairro das Estacas" (which means literally "Stakes Neighbourhood"), a popular name that still remains today. But it also got official recognition in 1954, by winning the Municipal Architecture Award as well as the Biennial of São Paulo Award, in Brazil. Its image of modernist buildings all aligned on top of round pillars was indeed a revolutionary proposal for a traditional city such as Lisbon in the early 1950's. It is worth mentioning that it was not just a question of architectural imagery: the urban space presented a totally new approach, with a parallel sequence of housing blocks (Fig. 2) and a public open space concept, replacing the traditional rectangular urban blocks envisaged in the original plan (see oval 1 in Figure 1).

Indeed, architects Ruy d'Athouguia and Sebastião Formosinho Sanches offered the city a new urban atmosphere (Fig. 3), based on 


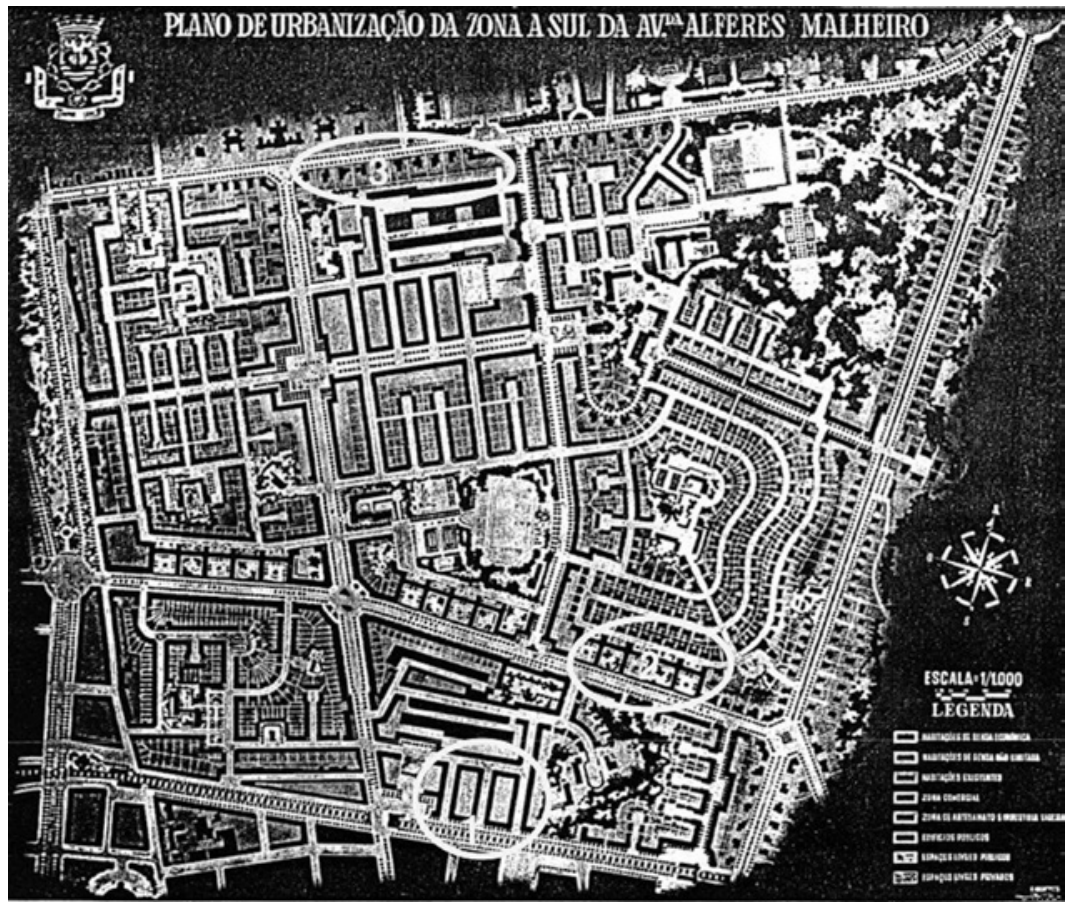

Fig. 1 "Alvalade Plan" designed by João Faria da Costa, 1945.

Fig. 2 Aerial view of Bairro das Estacas. Photo: unknown author, 1950's.

The contrast is clear between Bairro das

Estacas and the traditional fabric of the recent surrounding city. The modernist urban layout, by placing the buildings perpendicular to the train tracks, offers citizens the green space created in between and under the apartment buildings that hover on top of piloti.

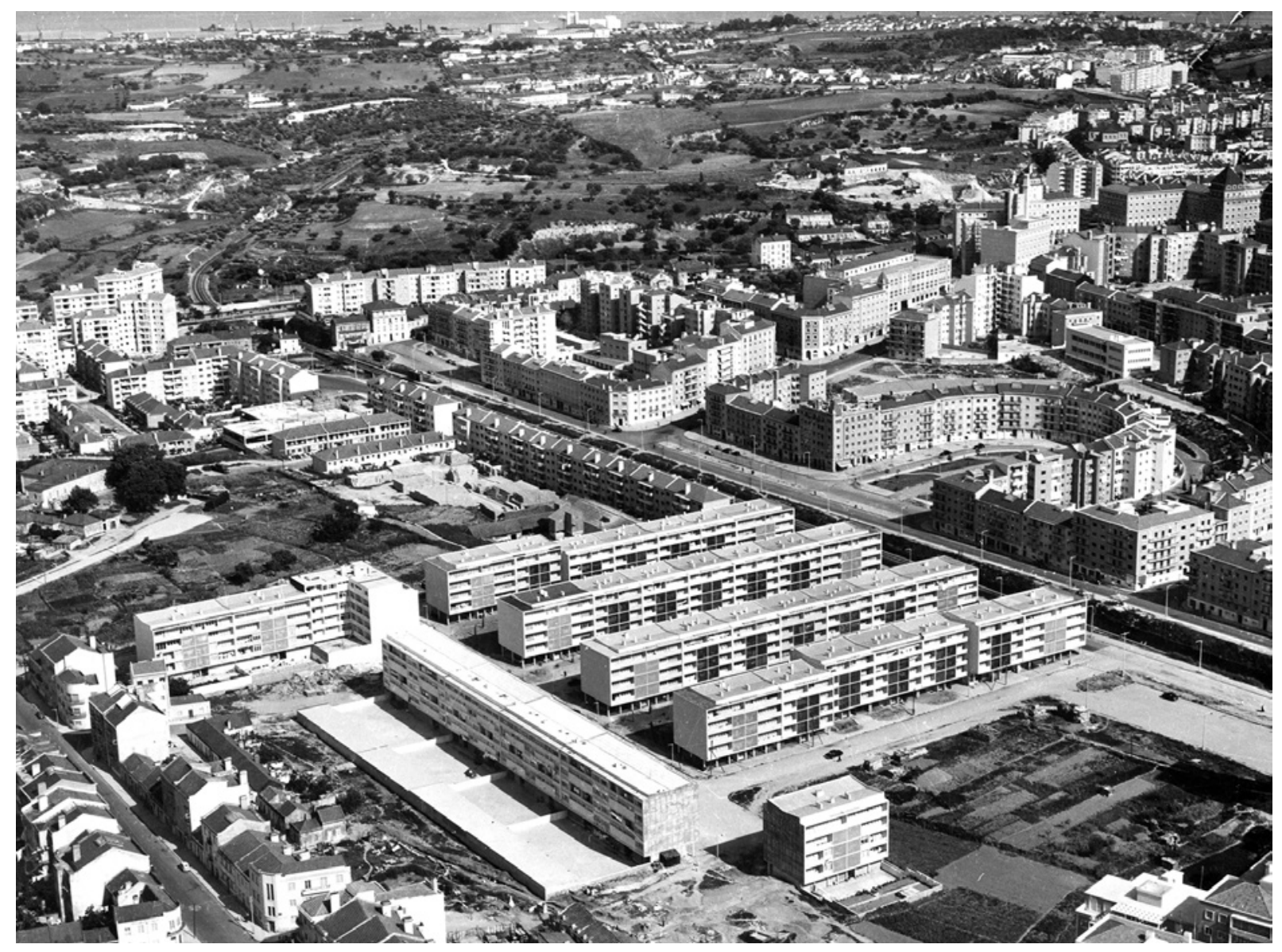


Fig. 3 View of the buildings open to the public garden. Photo: António Carvalho, 2018.

Architects: Ruy d'Athouguia, Formosinho Sanches, and Gonçalo Ribeiro Telles, 1949. The modernist transparency of the public garden: the scale and proximity of the buildings, with recessed balconies, provided a vicinity atmosphere as well as a feeling of protection and shadow.

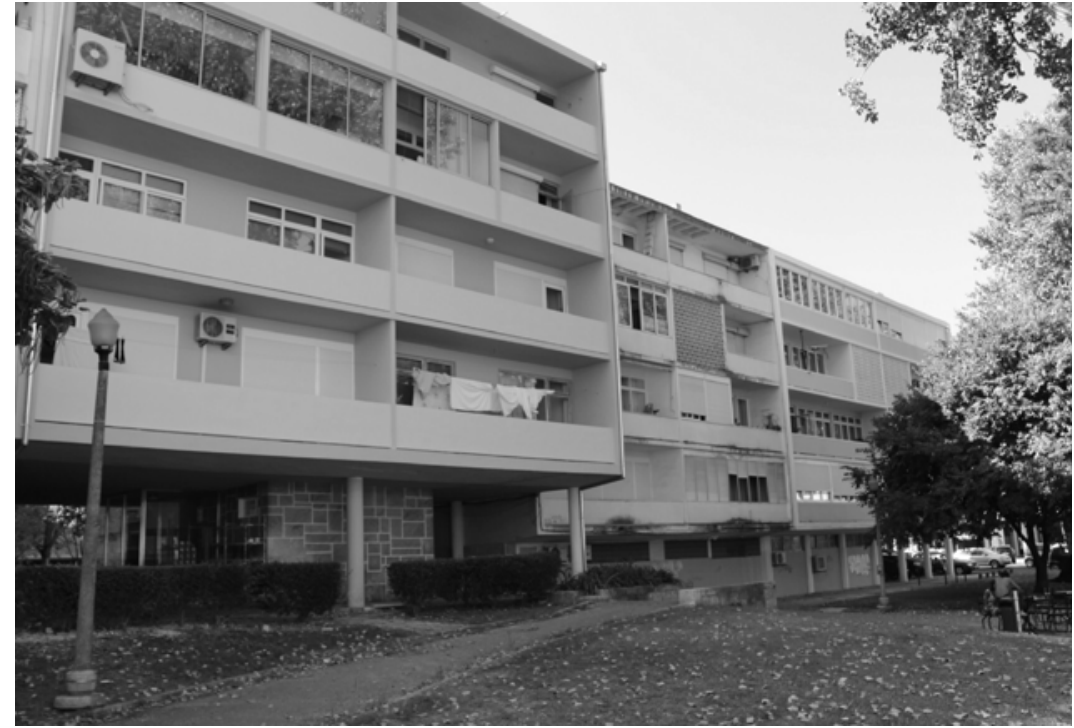

new housing types in modernist buildings hovering above a continuous public green space designed by landscape architect Gonçalo Ribeiro Telles (Fig. 4). Lisbon had a new way of living the urban space: a clever mix of commercial spaces on the ground floors, along the peripheral streets, protected from sun and rain by the recess created by the modernist piloti colonnades (Fig. 4). This was an invitation and opportunity for comfortable window-shopping, while the central buildings' pilotis offered visual permeability and public space continuity. The three green spaces in between buildings were thereby connected together, creating a continuous public park where children could easily play, overlooked by mothers from the apartment balconies (Fig. 3). The intelligence and generosity of this urban layout will prove to be of great flexibility for new reuses, six decades after its first MOD ${ }^{1}$ residents aged in place as we will see.

\section{Avenida dos Estados Unidos da Ámerica, 1954}

The avenue layout goes back to 1941 when the city planning department designed it to become the main outward traffic distributor in Lisbon, aiming to connect the forest park of Monsanto (on the western end) to the riverfront at Poço do Bispo (eastern end). Its construction was already in progress by the time Faria da Costa designed the Alvalade Plan, thereby incorporating its presence and influence. In fact, as we can see (Fig. 1), its northern side already presented a modernist layout of buildings standing perpendicularly to the avenue, creating public spaces in between them. By 1954, when the architecture team of Manuel Laginha, Vasconcelos Esteves and Pedro Cid designed the buildings in the north-eastern side of the avenue, they proposed a continuous green park on the ground level (much similar in design to the one at Bairro das Estacas), providing visual transparency and 
physical continuity, thanks to the generous span of the large piloti of the buildings (Fig. 5). The direct influence of Le Corbusier's Unités d'Habitation was clearly assumed by the authors for the taller buildings: ground floor on piloti, east-west full depth apartments with recessed balconies, modulated façades with sun louvers, a communal rooftop terrace. But for this case study, it is the apartments' layout that we'll be analysing below in further detail: its rational and optimal organization was quite generous in space, thereby allowing future adaptations and reuses. In fact, each apartment accesses a central entrance hall distributing the domestic sectors: services (kitchen, laundry, maid's room), social (living and dining room with recessed balconies) and private areas (bedrooms and bathroom). A secondary service door, accessed from the stairs, allows a service circuit separate from the family spaces. All these features will be useful for new uses (Fig. 8).

\section{Avenida do Brasil, 1958}

This set of buildings was designed in 1958 by Jorge Segurado who proposed a deep change in the 1945 urban layout: instead of having the buildings facing the avenue, the architect proposed to rotate them perpendicularly, hence with the longer elevations facing East-West and offering the North elevation to the avenue instead, in a modernist sequence of slender volumes (Fig. 6). These eight housing blocks, with seven floors each, only have car access from the secondary
Fig. 4 Plan of the public garden at Bairro das Estacas. Architects: Ruy d'Athouguia, Formosinho Sanches, and Gonçalo Ribeiro Telles, 1949. This plan shows the important role of the piloti alignments on the street elevations, creating protected paths along the shop windows. Moreover, it shows the central role of the public gardens, connected by organic pedestrian paths that go under the hovering buildings, in different directions.

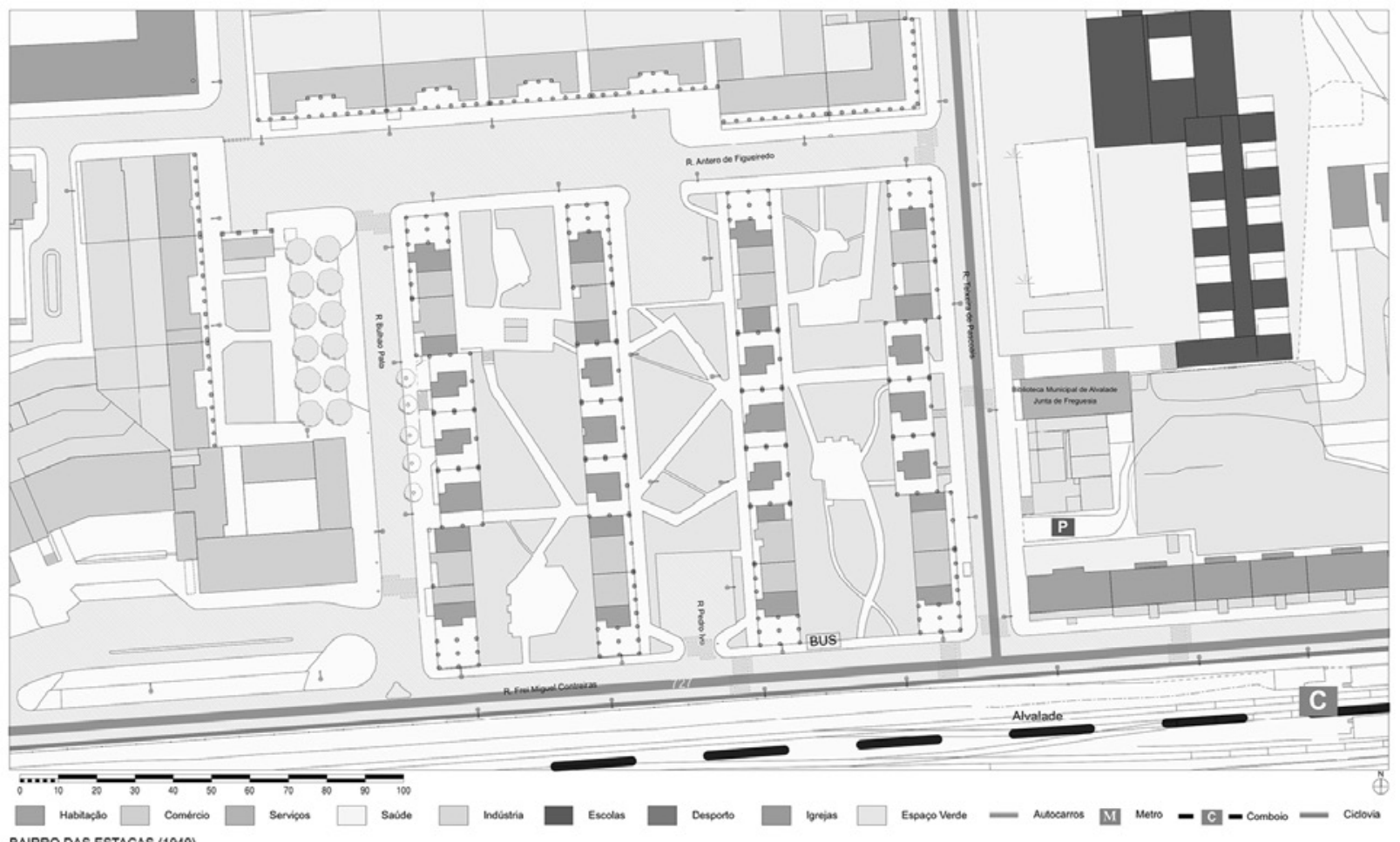


Fig. 5 The buildings along the avenue with the green public squares in between them. Photo: António Carvalho, 2018.

Architects: Manuel Laginha, Vasconcelos Esteves, Pedro Cid, 1954. street, parallel to the avenue. The space in between the buildings was thereby liberated to become a sequence of small squares and gardens, interconnected by pedestrian paths that continue under the piloti buildings, framed on the South side by single-floor buildings for commercial activities - a clever design choice which permitted some urban mix of uses, thereby introducing flexibility into the modernist zoning criteria.

The whole ensemble was promoted by and still belongs to the Montepio Geral bank, thereby controlling more effectively the global image and avoiding individual interventions in the apartments or in the buildings. This fact also enables the possibility of considering each building as a global entity, like a residential facility subject to common rules making it easier to propose new uses for the whole urban ensemble, in a privileged location: the university campus is located on the western end of the avenue, while the city airport roundabout is at the eastern end of Avenida do Brasil, along which several public main facilities are located.

\section{Alvalade in the 2000's: a NORC in the city}

The predictions for the 21st century say the world population will keep growing (UN, 2017): by the year 2100, the population in all continents

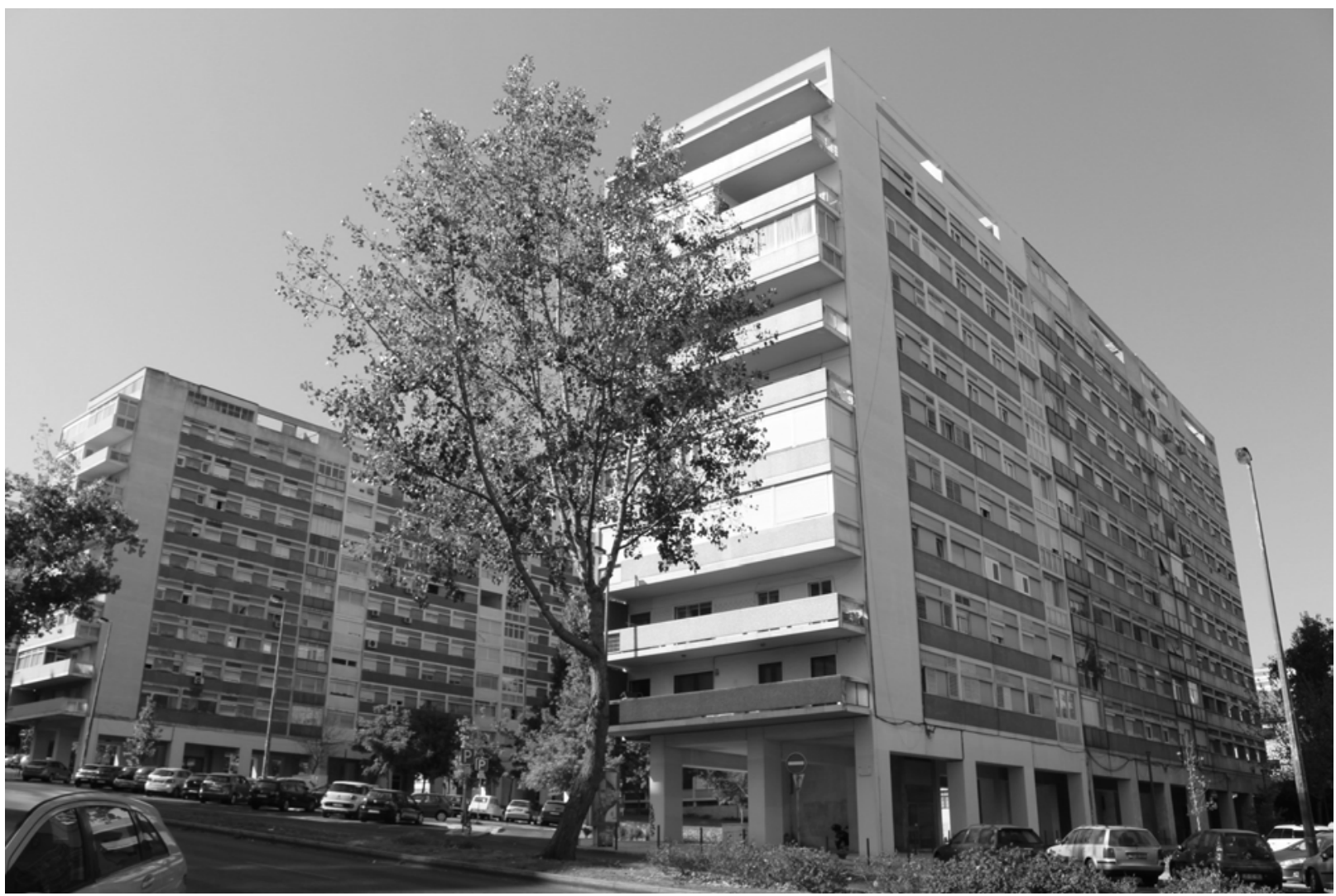


will have grown to a total of 11184 million - with the only exception of Europe whose population will continuously decrease. In Portugal, by the year 2030, the psychological threshold of 10 million will not be reached (just 9877000 Portuguese inhabitants by then), continuing to fall until the year 2100 when the total population will be of just 6604000 citizens (UN, 2017). Nevertheless, the most significant factor common to all continents is the fast ageing of the still growing population: globally, population aged 60 or over is already growing faster than all younger age groups. We accordingly say that the future will be grey (haired...) worldwide - and we must prepare our environments for it. In Lisbon, we will use the Alvalade Neighbourhood as our case study to find how some modernist spaces (of different scales) can be reused in a new societal context, totally different from the original one they were conceived for. In fact, Alvalade is now a NORC, that is, a Naturally Occurring Retirement Community: in the 2011 Census, it was already the second most aged district in Lisbon.

\section{Bairro das Estacas, today: public space for contemporary use}

Almost seven decades later, the public space of Bairro das Estacas shows a quite remarkable resilience, keeping most of its original features, compared to the buildings that suffered individual changes made by the apartment owners (mainly the closing of the recessed balconies with diverse window types, thus affecting the visual atmosphere of the urban space and the visual-social interaction between balconies and public gardens below).

Then, how can the public urban space be readapted or transformed towards the new needs of the aged community in the 21st century, and yet keep its original design features and quality?

Based on observation, site visits, and application of an accessibility checklist (Dischinger, Bins Ely and Piardi, 2009), we concluded that most of the needs can be fulfilled with quite minimal changes. The promotion of active ageing (WHO, 2002) has been adopted by public health institutions as a major policy for contemporary societies, for

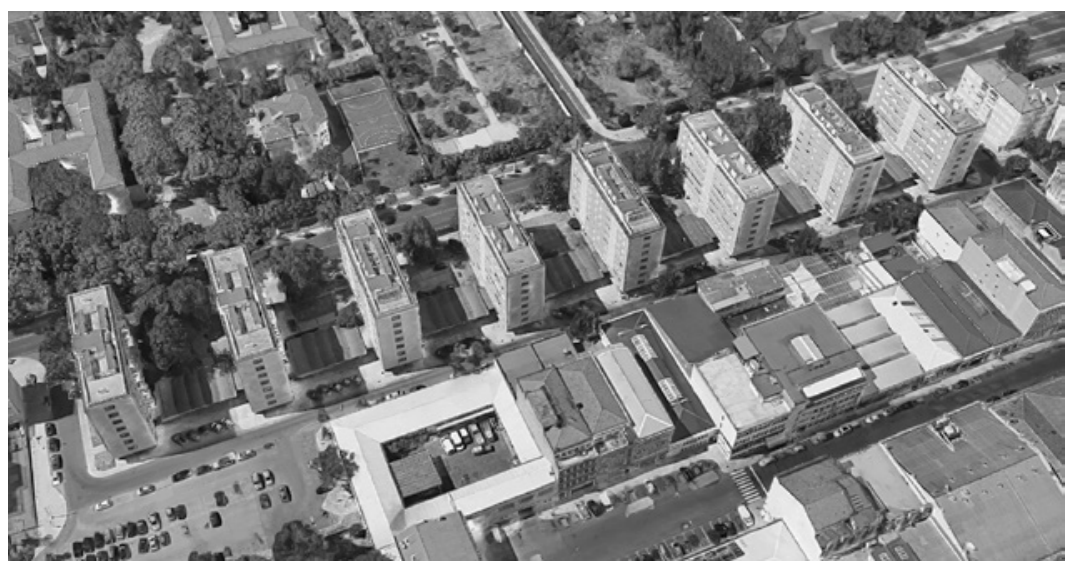

Fig. 6 Aerial view of the buildings along the avenue, seen from the South. Photo: Google, 2018. Architect: Jorge Segurado, 1958. We can see the modernist effect of the sequential volumes to be perceived from the traffic along the avenue. The housing blocks are connected by one-floor commercial buildings, recessed from the avenue and therefore creating small squares and gardens for public use. 
Fig. 7 Proposed Reuse of Public Space at Bairro das Estacas - ground floor plan. Author: António Carvalho, 2013.

Location of the new urban elements that older people need for a comfortable and safe use of public space, such as: zebra crossings, smooth but anti-slippery accessible paths, wheelchair parking spot parallel to garden bench, garden bench, drinking fountain, handrails in stairs, accessible ramp, parking place for drivers with impairments. which the use of public spaces is the main determinant. We therefore propose (Fig. 7): the transformation of some existing sidewalks into accessible pedestrian paths with smooth, levelled and non-slippery pavements (for wheelchair and all users); introduction of some ramps for accessibility; handrails on existing stairs for a more comfortable and safer use; maintenance of the vintage benches and introduction of new ones (in stronger materials, for obese people) under tree shadows, because it is an important asset for public space use since older people get easily tired and need to rest often; dedicated car parking places for people with impairments; some more zebra crossings; the introduction of traffic lights with sound timer at busier streets for safer crossing; drinking fountains in the park. The introduction of all these elements is totally compatible with the existing public space due to its clever original design, thus not requiring major changes in infrastructural works. But one essential public facility (Hanson, 2004) that is still missing is public toilets: its absence in public space restrains older people from going far away from home. To solve this problem, we propose to create this facility inside the existing market warehouse, therefore providing a free public alternative to private ones in existing cafés or restaurants.

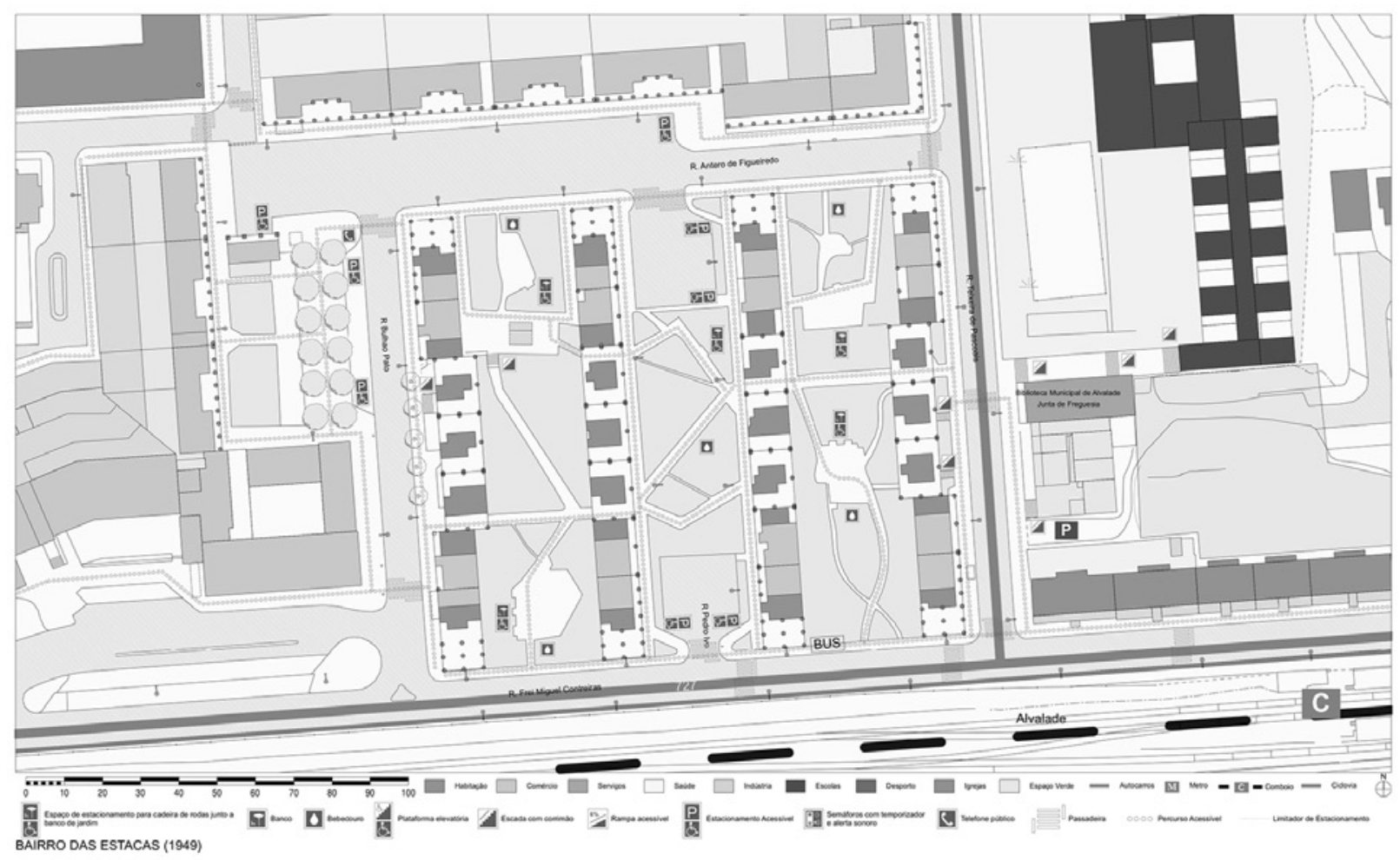




\section{Avenida dos Estados Unidos da Ámerica, today: age-friendly apartments}

We will consider for the purpose of this paper just the apartments of the five taller buildings (10 floors each) that face the avenue perpendicularly. While, therefore, in the previous case study we considered the reuse of urban space, now we will analyse in which ways the interior spaces can be adapted for older residents.

The longer life expectancy that modern medicine, as well as new habits and lifestyles, have brought to all of us (WHO, 2002), means among other things that people will be able to live longer in their homes and apartments - that is, if their spatial features allow it. In fact, most people would rather remain in their homes (Machado, 2007; Moreira, 2008) instead of moving into elderly facilities, so it is important that the space layout allows that to happen. Looking at the plan of the apartments at Av. E.U.A. (Fig. 8), we can conclude that the rational organization of the (not so big) spaces allows the access (dotted lines) and rotation (circles) of wheelchairs, with no need for demolitions. The only spaces that would require major adaptations would be the bathrooms and kitchens. But even in these complex and technical spaces, the most important aspect is to have the infrastructures (sewage, drains, water) in the correct positions, considering the expensive implications it would bring to the ten floor vertical pipe system. Thus, taking that into consideration, we can see that minor adaptations would allow flexibility of use throughout time for different people, of different ages, with different needs (Fig. 9): opening the door outwards would be recommendable for better circulation and safety (in case of need to break in for help after an accident); the shower placed in the centre, with a pavement drain, could easily have the cabin removed to be turned into a roll-in shower, accessible on a wheelchair; the double washbasin could be turned into a single basin, thus providing space to park a wheelchair parallel to the toilet. All these changes would not require alterations in the main vertical sewage pipes of the building, so they could be done individually according to each resident's needs and decision. Actually, the proper positioning of each device would later require just the addition of supporting bars (Fig 10), easily removable later when not necessary anymore.

The kitchens, designed in a modernist "functional corridor" layout (Fig. 5), could be quite easily adapted (Maguire, M. et al, 2011) as well for the worst-case scenario, which will always be the wheelchair user needs (Fig. 11), without changing any walls. The solution would thus lie in the distribution and design of the kitchen cabinets, reminding us that the most important and basic need is to provide empty space under the counters so that a person sitting on a wheelchair can fit the legs and approach the counter, the stove, the taps. For that purpose, we think that movable cabinets on wheels could be used to fill the space under the counter and, whenever necessary to be used by someone on a wheelchair, they could be removed without changes in 


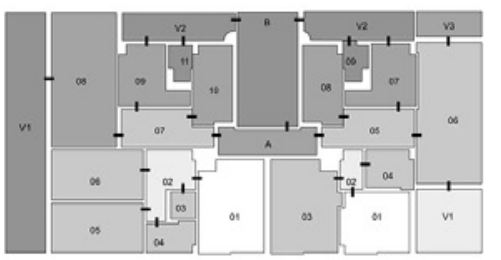

(1) (11) (12) (3)

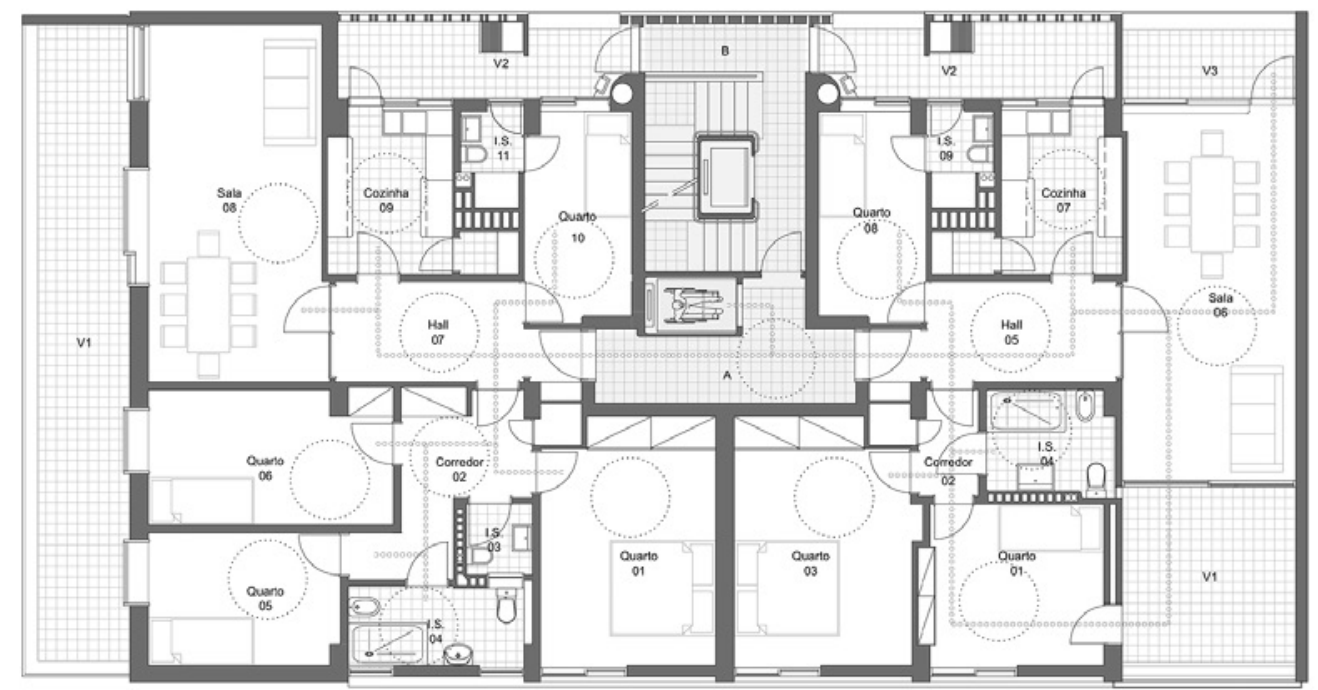

(9) (4) (क) (3) (4) (4) (क)

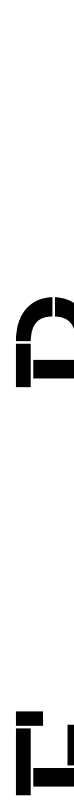

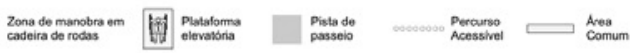

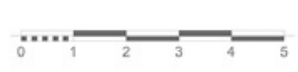

Proposta Planta dos Pisos
AV. ESTADOS UNIDOS DA AMERICA (1954)
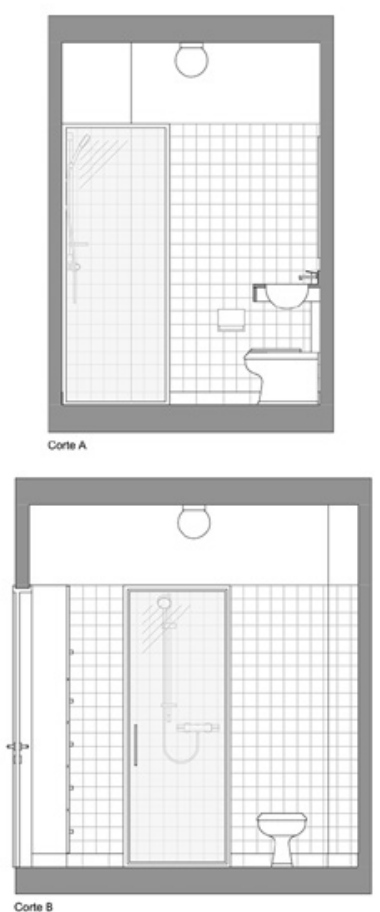
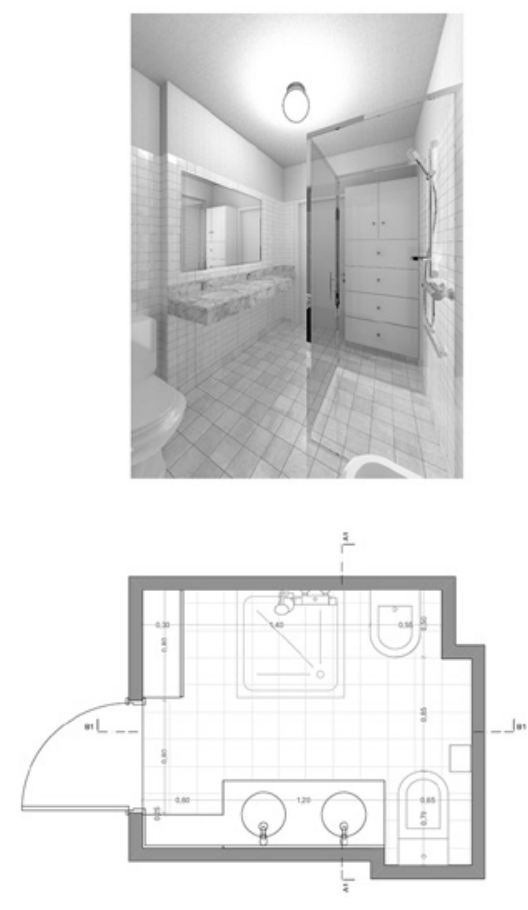
INSTALAC,AO SANITARIA- NORMAL

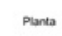




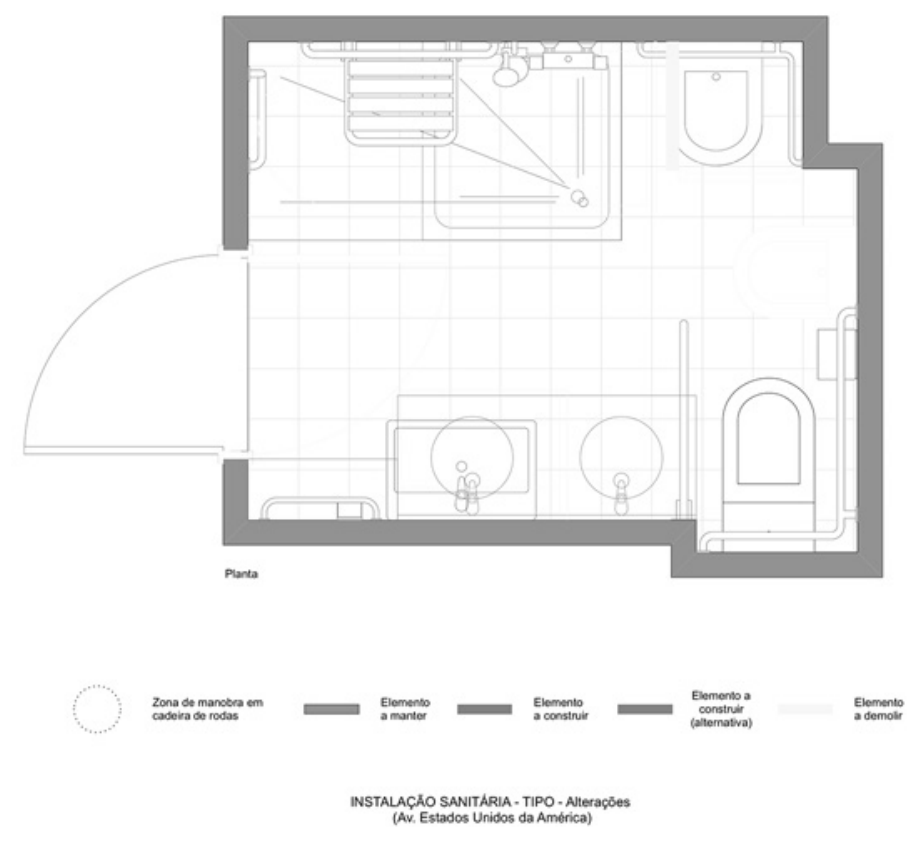

the infrastructures. The lower cabinets should all be provided with drawers the person on a wheelchair can easily access (but also any other adult can, with the great advantage of not needing to kneel or bend over to catch something in the distant back of the low cabinet). The upper cabinets, if necessary, can also be articulated and provided with a suspension system that brings down the interior shelves. Anyway, the main purpose is to provide flexible solutions that everybody, even the most fragile persons, can use with autonomy, thereby allowing them to remain in their apartments for as long as they want or their health allows: apartments for life.

\section{Avenida do Brasil, today: residential facilities for intergenerational living}

This group of buildings has special features that would justify turning some of them into intergenerational residential facilities: its location, very close to the university campus, makes it very attractive for university students, while the vicinity of many urban facilities and trading places makes it very comfortable for older people (Fig. 12). Taking into consideration the lack of student housing in Lisbon and the very large dimensions of most of the apartments, which are now empty nests for lonely older people (whose children have grown and left home to start an adult life), matching both groups could be a good opportunity for urban and social renovation.

Considering that there are 8 apartment buildings (with 7 floors each) of two types, A ( 5 buildings) and B (3 buildings), and 7 commercial
Fig. 8 Typical plan of the apartments with accessibility and simplified Space Syntax analysis. Author: António Carvalho, 2013 after architects Manuel Laginha, Vasconcelos Esteves, Pedro Cid, 1954.

Accessibility paths and rotation circles for wheelchairs are marked, proving that the apartments have easy accessibility. Kitchens and bathrooms would need some adjustments (see Figs. 9 and 10).

Fig. 9 Typical bathroom of the apartments proposal. Author: António Carvalho, 2013. If we compare this layout with the plan of the universal design bathroom solution (Fig. 10), the main conclusion is the importance of the correct location of the devices. Later, at an older age, or if special needs occur, the only thing necessary will be to add bars and choose a single washbasin.

Fig. 10 Typical bathroom of the apartments adapted for universal use. Author: António Carvalho, 2013.

Comparing with the plan of the typical bathroom solution (Fig. 9), we see the overlapping of washbasins as well as the added bars and shower seat. All these add-ons can easily be removed later again, with great flexibility, without changing the main infrastructures of the building. 

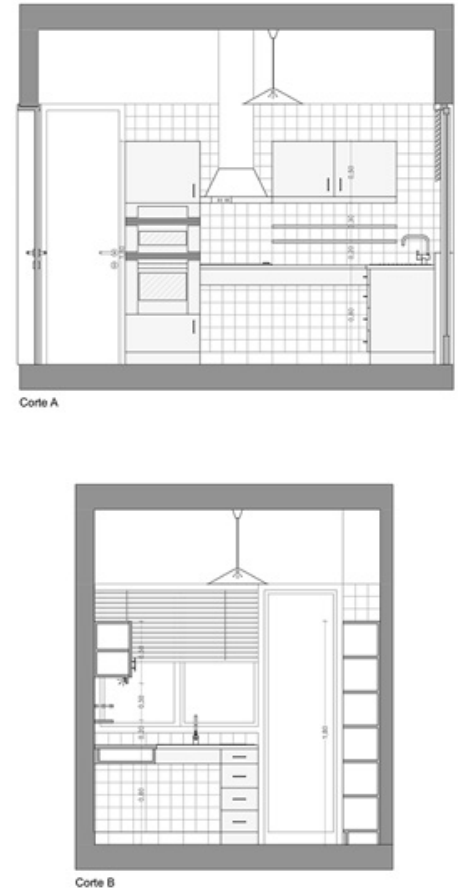
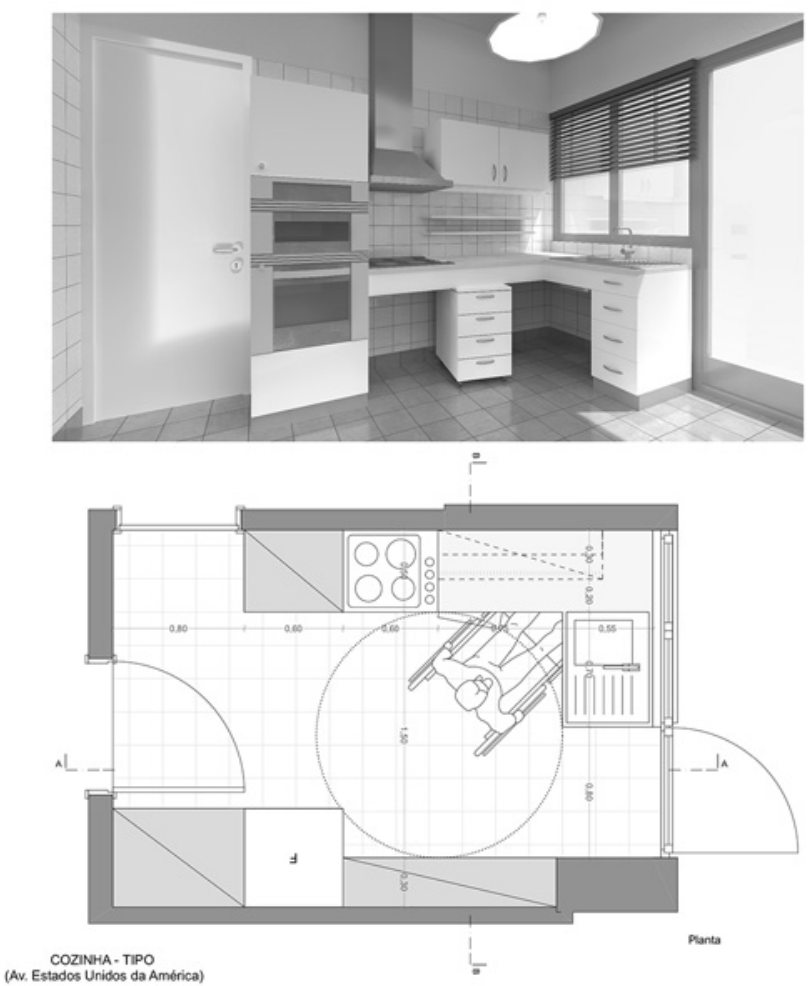

Fig. 11 Proposal: typical kitchen of the apartments adapted for universal use. Author: António Carvalho, 2013.

The use of removable cabinets under the counters would allow wheelchair users' autonomy. buildings (with ground floor only), we will consider for this proposal the reuse of type A only because they have the largest apartments. Starting at ground floor (Fig. 13), therefore, all existing spaces would be preserved and reused: the main entrance, in its glass-box features, would become a waiting lounge where residents could sit while they wait for a taxi, a friend or a relative, comfortably watching life outside; the storage space on the left would become a parking place for bicycles and electric wheelchairs; the doorman's apartment, on the right, would become a small reception (with a window for visual control of the lounge) and office for the new service providers working in the building, with a nurse/treatment room/doctor's office connected to the sanitary facility. No demolitions would be required.

The existing typical floor clearly corresponds to other times (1958) and a society when families were big, with housemaid help: a domestic office at the entry (which could become an extra bedroom), a big living and dining room with a generous balcony, a transition hall connecting to the family dining room, and the corridor to the children's and parents' bedrooms and bathrooms; a service entrance door connected to the stairs was dedicated to the housemaid and deliveries, opening directly to the kitchen and pantry, to which the housemaid's bedroom and sanitary facility are connected. This bourgeois housing structure is demonstrated by the simplified Space Syntax (Hillier and Hanson, 1984) analysis map and graph that show a deep space (seven 


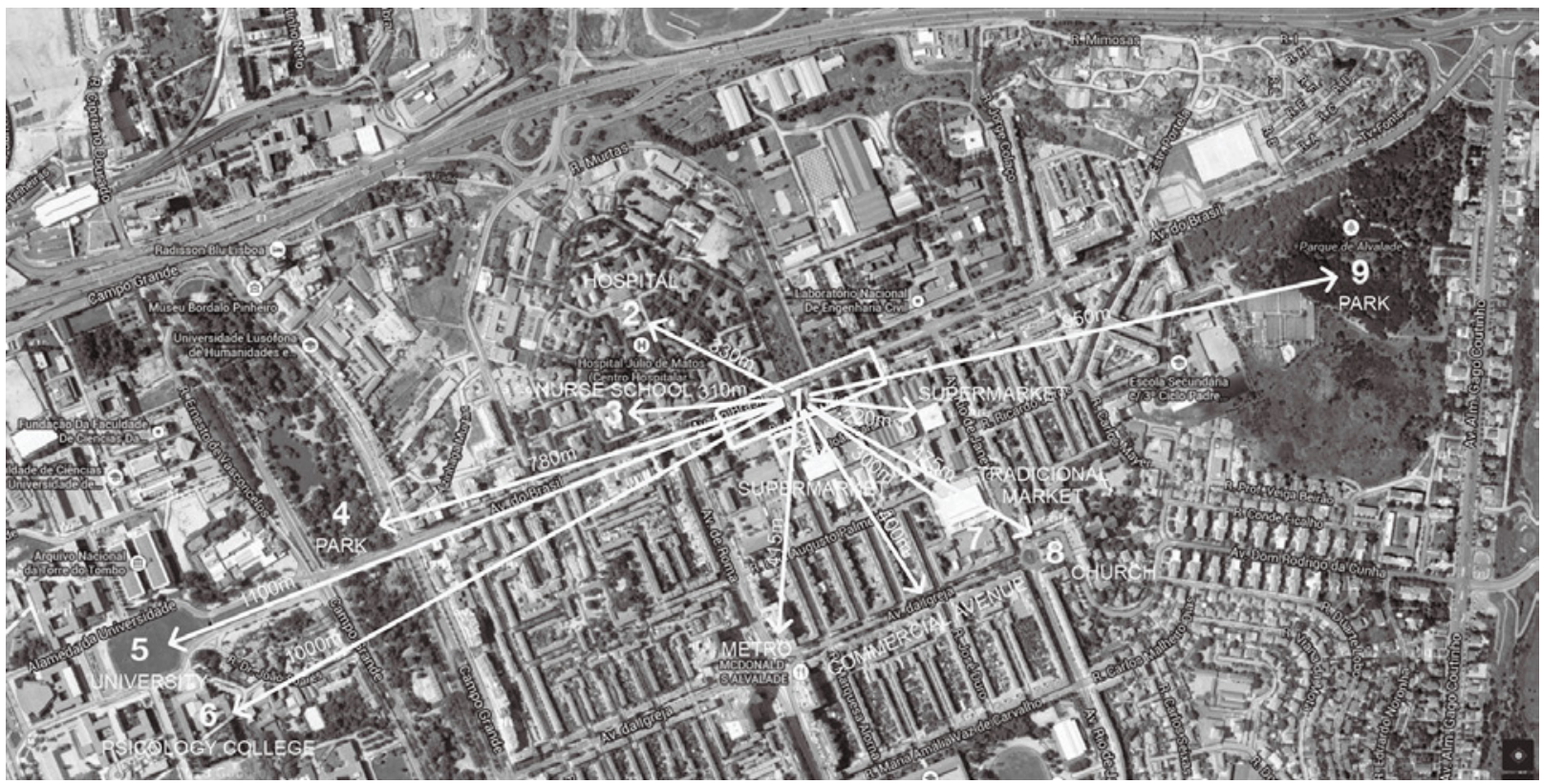

levels) and the maid's facilities quite segregated from the rest of the house. Nevertheless, this can become an advantage for contemporary intergenerational reuse: these large apartments could easily be shared by university students and its original older residents, who would become hosts, benefitting from younger people's company and help. This kind of experience, exchanging lodging for company and casual help, is not new and has proven to be successful (Fundação para o Desenvolvimento Social do Porto, 2003).

In our case, it would be a quite natural solution to organize the apartment into two sectors, eastern and western (Fig. 14). Students would have 3 individual bedrooms, sharing 2 sanitary facilities (the former corridor to the master bedroom is now reused for a shower space) and the big living room, good for group work and leisure, with the balcony. Older residents would use the western spaces: the master bedroom would gain a private bathroom (fully accessible with a rollin shower for wheelchair use, in the worst-case scenario) and direct access to the smaller living-dining room and kitchen, therefore keeping within a short range the essential spaces for their daily living activities (Zimmerman, Sloane and Eckert, 2001), which we as architects must be attentive to (Buse et al., 2016). They would still keep for their own use the extra small room (the former housemaid's bedroom), quite ideal to host relatives overnight or even a nurse or another caregiver. Nevertheless, some spaces would be shared by all, older and younger: the entrance hall that can immediately distribute the two parallel paths with full autonomy, and also the kitchen, pantry, and the sanitary facility. With this distribution and very minimal interventions (just closing and opening doors to connect existing spaces in a different way),
Fig. 12 Aerial photo (Google, 2015). Author: António Carvalho, 2015.

Building ensemble (1) and the distances to important facilities: 2- Hospital $(330 \mathrm{~m})$, 3- Nurse School (310m), 4- Park (780m), 5- University Campus (1100m), 6- Psychology College $(1000 \mathrm{~m}), 7-$ Traditional Market $(300 \mathrm{~m}), 8$ - Church $(475 \mathrm{~m}), 9-$ Park $(950 \mathrm{~m})$, Supermarkets $(120 \mathrm{~m}$ or $220 \mathrm{~m})$, Metro Station $(415 \mathrm{~m})$, Commercial Avenue (400m). 
Fig. 13 Ground floor level. Photo: António Carvalho, 2018. Architect: Jorge Segurado, 1958.

Green square between the buildings. The central building is dedicated to commerce. On the right, the glass box of the apartment buildings entrance.

Fig. 14 Proposal for a typical floor plan of the apartment buildings, organized into Eastern and Western sectors. Author: António Carvalho, 2013.

Students would occupy and share the spaces in the Eastern side of the apartments: 3 individual bedrooms $(05,06,15)$, the large living and dining room (08), the balcony (V1), and 2 sanitary facilities (03). The older residents would occupy the Western side: the master bedroom (01) with private accessible bathroom (04), the little living/dining room (09), the extra bedroom (11) and shared sanitary facility (12). The entrance hall (14), the pantry and the kitchen (13) would be shared by all. The simplified Space Syntax map and graph show a shallower (5 levels) and less segregated space than initially.

Fig. 15 Proposal of new spaces - rooftop plan. Author: António Carvalho, 2013.

From left to right: outside terrace, restaurant, gym, sanitary facility, kitchen, elevator and stairs, lounge, sanitary facility, laundry, clothes drying, outside terrace. All along the perimeter, there will be a walking path (approximately $75 \mathrm{~m}$ long) which residents can use for daily exercise.

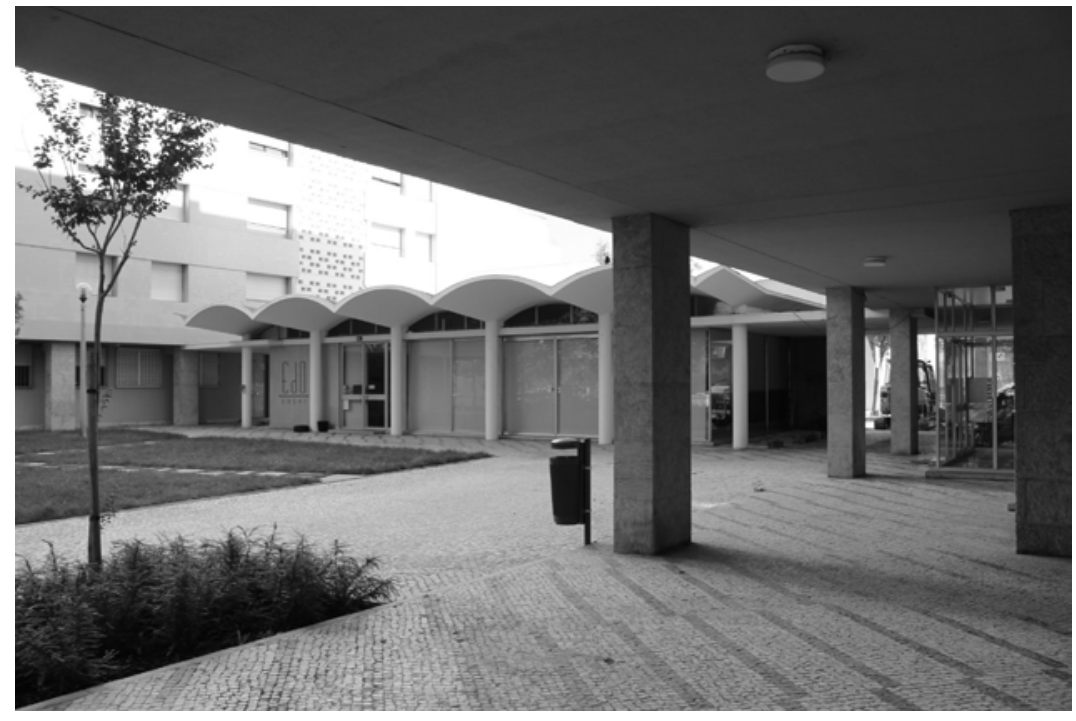

older and younger residents could have simultaneous activities without disturbing each other's privacy and yet keep company by sharing the same big apartment.

We have mentioned before the importance of active and healthy ageing (WHO, 2002), which implies that people should not remain indoors (both young and old) but rather keep active, going out and socializing (Carvalho, 2017). But for very old and fragile people, this could be a problem though, because very often the sidewalk pavements are uneven, slippery, or poorly maintained (Machado, 2007), thus going out becomes a hazard and a risk. Fortunately, these buildings have flat roofs, where we can create an alternative for that (Carvalho, 2013), at least for the days when people do not feel like going outside the building, but can still socialize and do some soft exercise (Fig. 15). Back in 1958, this flat roof was dedicated to individual laundry and drying spaces for each apartment (Fig. 6) which the housemaids used on a daily base, being totally abandoned nowadays. Our proposal is accordingly to demolish those small partitions of the laundries and create some common spaces for all residents, so that this top floor can become a service and leisure area. We propose the creation of outside terraces where residents (young and old) can sit and socialize while watching others exercising on the walking path (Fig. 16), as well as the creation of a restaurant (Fig. 17) where residents could come and eat whenever they did not feel like cooking or eating alone. A small gym (Fig. 18) would be an attraction for residents of different ages, for some in-house exercise and socialization. A lounge (Fig. 19) would also be an alternative space to the terraces for indoor socialization, internet browsing, book exchanges or just friendly talk. The restaurant and all the other facilities would be managed and maintained by a professional team based on the ground floor office (Fig. 13), taking care 

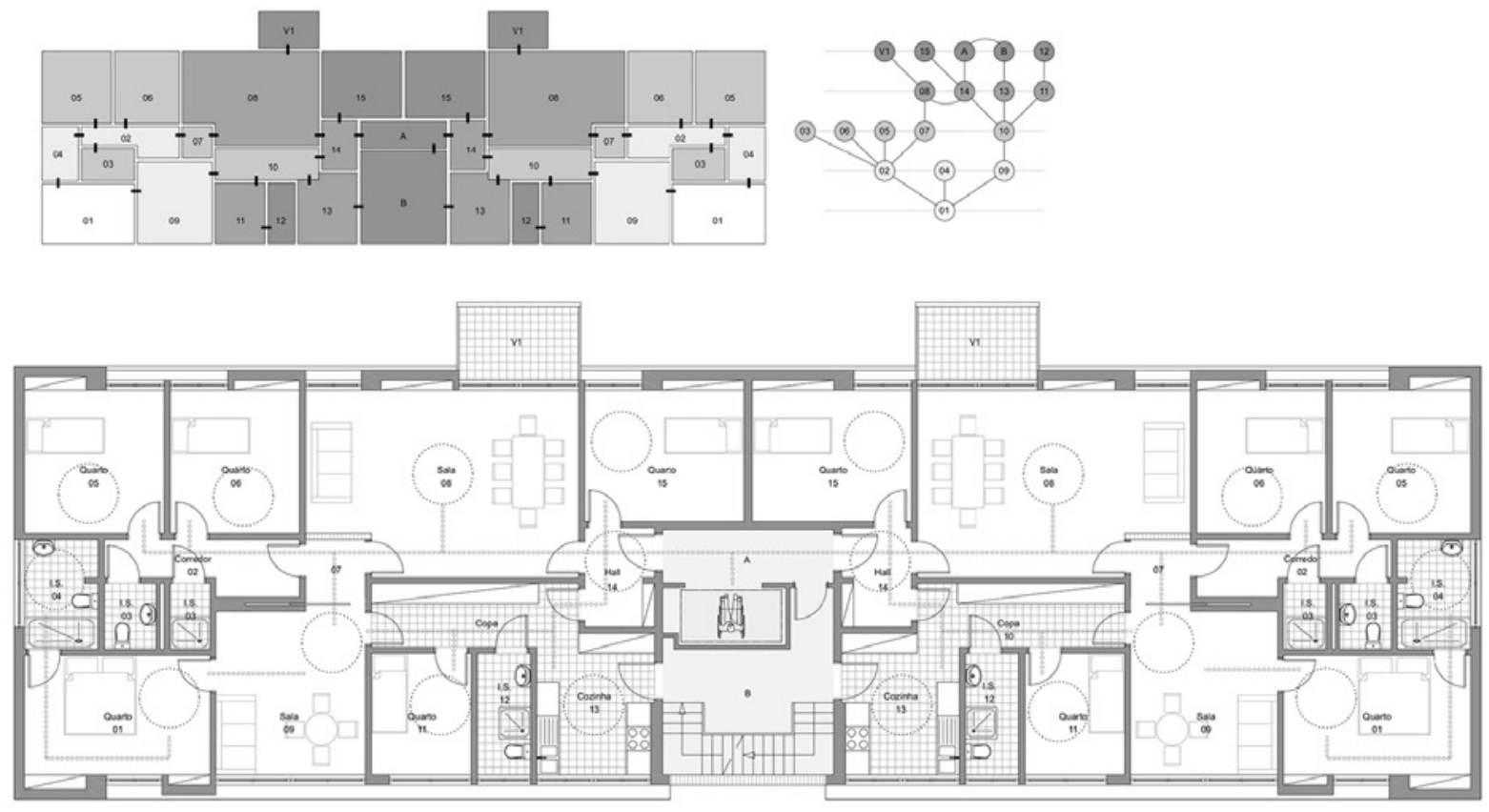

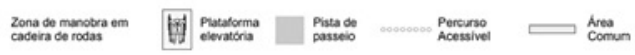

Proposta 2

Planta dos Pilos
AV. DO BRASLL (1958)

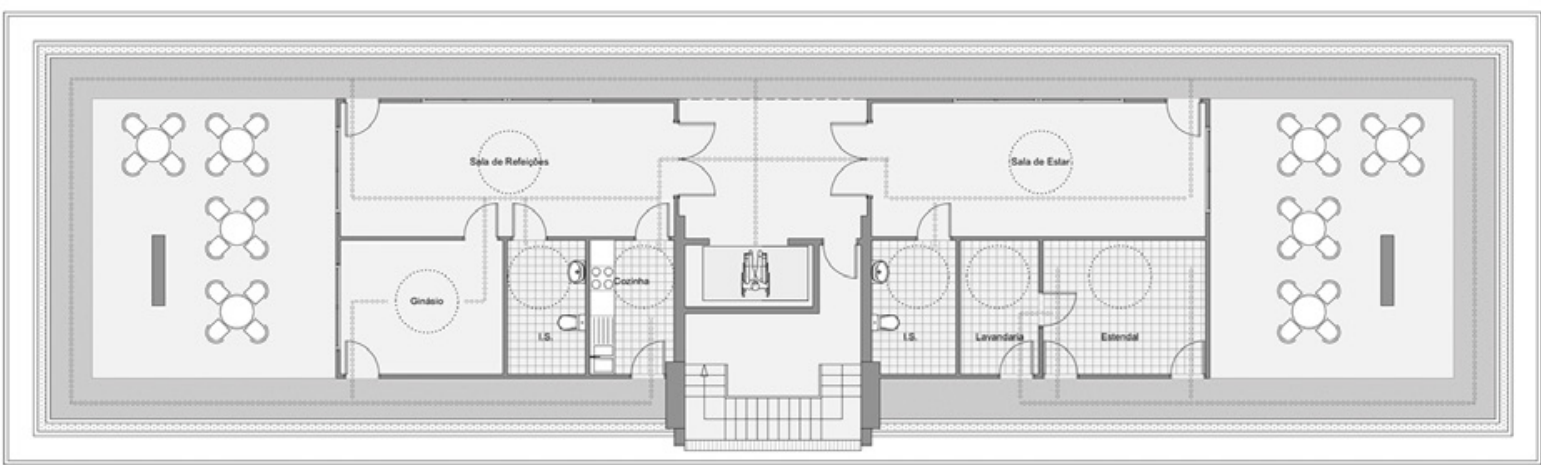

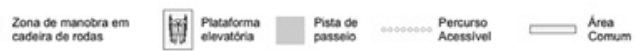
Planta do Tereraco
AV. DO BRASIL(1058) 
of the whole building in an assisted living facility logic, also providing some healthcare and psychological support, for which the vicinity (Fig. 12) of the Nurse School and Psychology College is very convenient, facilitating internships and protocols to be celebrated with the residents' community.

\section{Conclusion}

In terms of reuse of modernist spaces, these three case studies can provide us some conclusions:

Urban space - the modernist option of wider and more visually transparent public spaces, with highly qualified landscape design, has proven to be a resilient solution, still used and appreciated today, almost seven decades later. In terms of reuse, the required elements and facilities can be easily added because the main asset exists already: public space. Therefore, it will be easy to add some more public benches, some dedicated car parking places for people with impairments, drinking fountains, ramps, handrails on stairs, traffic lights with sound timers, and zebra crossings. From the existing organic web of pedestrian paths, some should be selected to be repaved with smooth, even and non-slippery pavement connecting the main points of the neighbourhood. The existence of commercial spaces on the ground floor of the apartment buildings is a plus for urban life with the mix of functions, providing the possibility of new uses according to new needs.

Apartment layouts - the clear modernist organization of interior spaces makes it quite easy to adapt to new accessibility requirements, like wheelchair use (in the worst-case scenario) or walking aid devices (walkers, walking sticks, crutches, etc.) that older residents sometimes need even inside their homes. In fact, we can conclude that most spaces, even when not too big, are wide enough for accessibility, presenting a quite straightforward layout that helps older residents move around. The only spaces that will require deeper intervention will be bathrooms, where the doors should open to the outside (for safety reasons, in case of need to break-in for help) and bathtubs should be replaced by roll-in showers with pavement drains. The other sanitary devices, whenever correctly located, would just require the addition of supporting bars. Therefore, the strategic location of all sanitary devices is key for future flexibility of use. In the kitchens, accessibility has not only to do with wheelchairs, but also the simple reaching out to get something on a top shelf or lower cabin can be a daily strain. Therefore, ergonomics should be a key concern in kitchen design both for the free space and especially for the cabinets and furniture.

Residential facilities - modernist apartment buildings, whenever conceived for simple communal life, that is, having some shared spaces belonging to all residents, could be transformed into assisted living facilities because those common spaces are the basis to allocate the required services that will support the new needs of an ageing population. This way, some basic spaces such as a restaurant with 

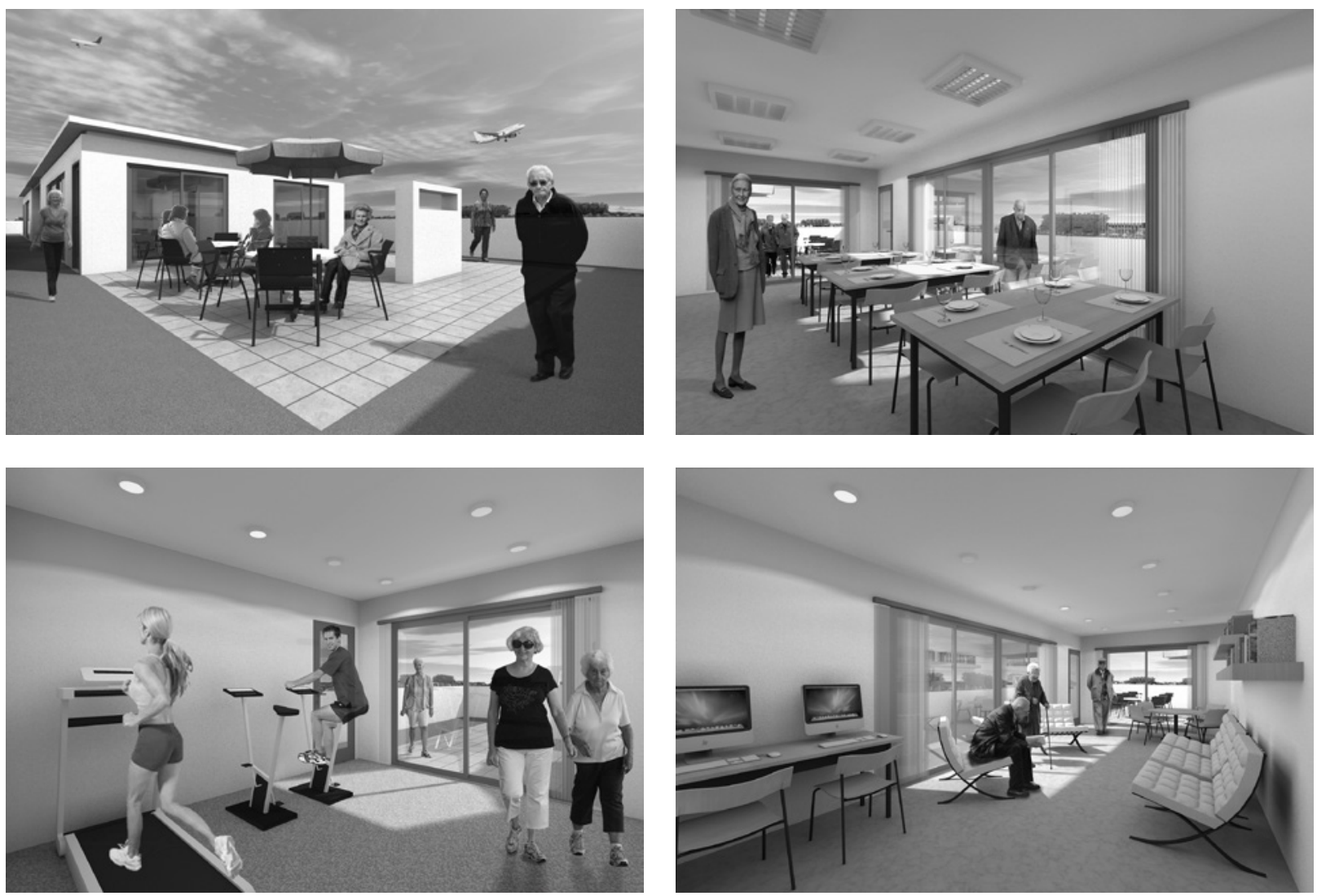

kitchen, a lounge, a laundry, and a treatment/nurse room, could be introduced in the existing spaces, reusing common areas such as the doorman's apartment, storage spaces, and flat rooftop spaces. Whenever the larger dimensions allow it, some intergenerational and cohousing experiences could also be introduced, provided that the previous match of younger and older residents is supervised by psychology experts who should follow up the new housing partnership.

Considering these different features, we would therefore conclude that the reuse of modernist spaces to be adapted to older residents is a promising future for our ageing societies, preserving in new ways a highly qualified modernist heritage.
Fig. 16 Proposal for rooftop: terrace and walking path. Author: António Carvalho, 2015.

Fig. 17 Proposal for rooftop: restaurant space. Author: António Carvalho, 2015.

Fig. 18 Proposal for rooftop: gym. Author: António Carvalho, 2015.

A small gym space would attract people of different ages, promoting interaction and socialization.

Fig. 19 Proposal for rooftop: lounge space. Author: António Carvalho, 2015.

A relaxing area to meet neighbours, chat, browse the internet, and exchange some books and ideas.

$1 \rightarrow$ MOD: 1-(adjective) modern; 2-(noun) especially in the early 1960s, a young person of a subculture characterized by stylish dress, the riding of motor scooters, and a liking for soul music; 3-(origin) abbreviation of Modern or Modernist. Source: New Oxford American Dictionary. 
Buse, C., Nettleton, S., Martin, D. and Twigg, J. (2016). Imagined bodies: architects and their constructions of later life. Ageing and Society. Available on: CJO 2016 doi:10.1017/ S0144686X16000362. [accessed on 28 September 2017].

Carvalho, A. (2010). Residências Assistidas - Projecto de Investigação Qualidade dos Equipamentos Sociais, Outras Formas de Habitar. Lisboa: LNEC.

Carvalho, A. (2013). Habitação para idosos em Lisboa: de colectiva a assistida. O caso de Alvalade. [Housing for the elderly in Lisbon: from multifamily housing to assisted living. The Alvalade case study]. PhD thesis. Instituto Superior Técnico da Universidade Técnica de Lisboa.

Carvalho, A. (2017). Never too old to move: the elderly and the city. In: Oosterbeek L., Gudauskas R., Caron L., eds. 2017. Education, training and communication in cultural management of landscapes. Transdisciplinary Contributions to Cultural Integrated Landscape Management. Mação: Instituto Terra e Memória, série Arkeos, vol. 42, pp. 68-83.

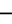

CML - Câmara Municipal de Lisboa (1948). A Urbanização do Sítio de Alvalade. Lisboa: Edições CML.

-

Costa, J.P. (2002). Bairro de Alvalade - um paradigma no urbanismo português. Lisboa: Livros Horizonte.

Dischinger, M., Bins Ely, V.H.M., Piardi, S.M.D.G. (2009). Promovendo acessibilidade espacial nos edifícios públicos: programa de acessibilidade às pessoas com deficiência ou mobilidade reduzida nas edificações de uso público. Florianópolis: s.n.
Fundação para o Desenvolvimento Social do Porto (2003). Regulamento do Programa Aconchego da Fundação para o Desenvolvimento Social do Porto [pdf]. Available at: www.bonjoia.org/files/ Regulamento_Aconchego.pdf [accessed on 24 de July 2012]

Gonçalves, C., Carrilho, M.J. (2007). Envelhecimento Crescente Mas Espacialmente Desigual. Revista de Estudos Demográficos, Pages 21-37, N.40.

Hanson, J. (2004). The inclusive city: delivering a more accessible urban environment through inclusive design. In: (Proceedings) RICS Cobra 2004 International Construction Conference: responding to change. York.

Hillier, B. and Hanson, J. (1984). The Social Logic of Space. Cambridge: Cambridge University Press.

Machado, P. (2007). As malhas que a (c)idade tece Mudança social, envelhecimento e velhice em meio urbano. Lisboa: Laboratório Nacional de Engenharia Civil.

Maguire, M. et al. (2011). Age friendly kitchens: a study based on social history and ergonomics. In: Include 2011 Proceedings. th $^{\text {th }}$ International Conference on Inclusive Design: The Role of Inclusive Design in Making Social Innovation Happen. Royal College of Art, London, UK, $18^{\text {th }}-20^{\text {th }}$ April.

-

Moreira, M.F.C. (2008). O Envelhecimento da População e o seu Impacto na Habitação - Prospectiva até 2050. Master dissertation. Instituto Superior de Estatística e Gestão de Informação da Universidade Nova de Lisboa.
Pastalan, L., ed. (1990). Aging in Place: The Role of Housing and Social Supports. New York: The Haworth Press Inc.

Perry, C. (1929). The Neighborhood Unit. [pdf] Available at: http://codesproject.asu.edu/node/11 [accessed on 1 October 2012]

$-$

UN - United Nations, Department of Economic and Social Affairs, Population Division (2017). World Population Prospects: The 2017 Revision, Key Findings $\&$ Advance Tables. Working Paper No. ESA/PI WP/248. New York: United Nations.

WHO - World Health Organization (2002). Active Aging: a Policy Framework. [pdf] Geneva: WHO. Available at: whqlibdoc.who.int/hq/2002/who_ nmh_nph_02.8.pdf [accessed on 12 October 2012].

WHO - World Health Organization Regional Office for Europe (2017). Towards More Physical Activity in Cities. [pdf] Geneva: WHO. Available at: http://www. euro.who.int/en/health-topics/disease-prevention/ physical-activity/publications/2017/towards-morephysical-activity-transforming-public-spaces-topromote-physical-activity-a-key-contributor-toachieving-the-sustainable-development-goals-ineurope-2017 [accessed on 12 May 2018].

Zimmerman, S., Sloane P.D. e Eckert, J.K., eds. (2001). Assisted Living: needs, practices, and policies in residential care for the elderly. Baltimore: The John Hopkins University Press. 